\title{
Swinging between finding and justification: judicial citation and international law-making
}

\author{
Letizia Lo Giacco* \\ LL.D. Candidate in International Law, Lund University Faculty of Law, Sweden
}

\begin{abstract}
Based on the ever-increasing interpretation and application of international law by domestic courts, this paper offers an insight into the practices of judicial citation of international and domestic jurisdictions while adjudicating international criminal law related matters. The paper considers selected instances of judicial citation and operates a prima facie distinction between judicial citation as a finding device and as a justification exercise. It is argued that domestic courts rely on international judicial decisions primarily as a finding device whilst international case law deals with domestic judicial decisions in the realm of justification. The analysis of this material triggers reflections on the relevance of judicial citation for the doctrine of sources of international law, inasmuch as it adds to the formation of normative expectations on subjects of international law, as well as for a scholarly conceptualisation of contemporary international law-making.
\end{abstract}

Keywords: judicial citation, judicial decisions, domestic courts, international law-making

\section{INTRODUCTION}

A decade ago, Anne-Marie Slaughter and William Burke-White published an article prophetically entitled 'The Future of International Law is Domestic'. ${ }^{1}$ Their contribution drew attention to new mechanisms whereby international law could 'backstop, strengthen and compel domestic law and institutions'. ${ }^{2}$ Indeed, the domestic ${ }^{3}$ is gaining momentum in international law. ${ }^{4}$ In particular, domestic courts as appliers and interpreters of international law catalyse scholarly reflection, insofar as they determine issues pertaining to international law and, to some extent, perform an international

* The arguments contained in this paper were presented at the ESIL Research Forum held at Koç University in Istanbul (April 2016). I sincerely thank Professor André Nollkaemper and Professor Christina Binder for their insightful comments on an earlier version of this paper, as well as the Editors of the ESIL SSRN Series of Papers and Professor Ulf Linderfalk for their remarks on later versions thereof.

1. A-M Slaughter and W Burke-White, 'The Future of International Law is Domestic (or The European Way of Law)' (2006) 47 Harvard International Law Journal 327.

2. Ibid 330.

3. Throughout this paper, 'domestic' is used interchangeably with 'national' and 'municipal'.

4. See, for example, S Weill, The Role of National Courts in Applying International Humanitarian Law (OUP, Oxford 2014); H P Aust and G Nolte, The Interpretation of International Law by Domestic Courts - Uniformity, Diversity, Convergence (OUP, Oxford 2016); E Benvenisti, 'Reclaiming Democracy: The Strategic Uses of Foreign and International Law by National Courts' (2008) 102 AJIL 241; Y Shany, 'Seeking Domestic Help - The Role of Domestic Criminal Law in Legitimizing the Work of International Criminal Tribunals' (2013) 11 JICJ 5. 
judicial function. ${ }^{5}$ In the realm of international criminal law, Article 1 of the Rome Statute of the International Criminal Court (Rome Statute) ${ }^{6}$ epitomises one such enforcement mechanism as it enshrines the principle of complementarity and acknowledges the primacy of national criminal jurisdictions in the prosecution of international crimes. This principle is reinforced by the preamble of the Rome Statute which recalls the duty of every State to exercise its criminal jurisdiction over those responsible for international crimes, ${ }^{7}$ and emphasises the role of national institutions and measures in the effective prosecution of those crimes. ${ }^{8}$

From the establishment of the UN ad hoc tribunals in the 1990s, domestic jurisdictions have experienced a remarkable advance in the adjudication of international crimes. ${ }^{9}$ If we accept that domestic judicial decisions on points of international criminal law are on the rise, ${ }^{10}$ and that the case law on international criminal law will likely exhibit a domestic pedigree rather than an international one, one may reasonably anticipate that relevant international and domestic judicial decisions will evidence new avenues of interaction. ${ }^{11}$ And yet it seems reductive to explain the increasing focus on national jurisdictions solely by way of arguments relating to the enforcement of international law. Plainly, the enforcement of international obligations is crucial for the involvement of domestic courts in the interpretation and application of international law, but it does not explain how national courts reach decisions on points of international law, nor for what purpose national courts cite prior international and foreign national case law. In other words, implementing international obligations incumbent on national institutions, including courts, has the potential of explaining why domestic courts embark on the activity of interpreting and applying international law but has little to say on why courts refer to their international and/or foreign counterparts' prior judicial decisions. Similarly, the practice of international courts citing national judicial decisions cannot simply be explained by resorting to international customary law arguments, or by reference to the argument regarding the determination of general principles of international law. Notably, some commentators have examined this latter phenomenon through the legitimacy lens, arguing that the practice of citing

5. Y Shany, 'No Longer a Weak Department of Power? Reflections on the Emergence of a New International Judiciary' (2009) 20 EJIL 73, 74. See also B Conforti, International Law and the Role of Domestic Legal Systems (Martinus Nijhoff Publishers, Leiden 1993); A Roberts, 'Comparative International Law? The Role of National Courts in Creating and Enforcing International Law' (2011) 60 International and Comparative Law Quarterly 57.

6. Rome Statute of the International Criminal Court (adopted 17 July 1998, entered into force 1 July 2002) 2187 UNTS 90.

7. Ibid preamble, sixth recital.

8. Ibid preamble, fourth recital.

9. During this time, about thirty countries initiated proceedings for international crimes based on territorial or active nationality jurisdiction. Seven trials were set up in Europe, eleven in Latin America, four in Asia and ten in Africa. See J Rikhof, 'Prosecution of International Crimes - a Historical and Empirical Overview' (2014) 2 Bergen Journal of Criminal Law and Criminal Justice 108, 114.

10. As noted by William Burke-White, 'the opportunities for enforcement of international criminal law are far more promising at the national than at the supranational level. International criminal law enforcement is effectively migrating from international tribunals to national courts.' See W Burke-White, 'A Community of Courts: Toward a System of International Criminal Law Enforcement' (2002) 24 Michigan Journal of International Law 1, 3. 11. This is in consonance with the idea of courts in dialogue with one another. For a thorough reflection on the point, see A Nollkaemper, 'The Role of Domestic Courts in the Case Law of the International Court of Justice' (2006) 5 Chinese Journal of International Law 301. 
domestic judicial decisions by international jurisdictions is embedded in a legitimisation process. ${ }^{12}$ Other commentators have pointed instead to the notion of "persuasive value' in order to explain the phenomenon of judicial citation in international law. ${ }^{13}$

Judicial citation as an element of interaction between domestic and international courts is the focus of this paper. It should be no surprise that domestic courts refer to prior international judicial decisions, nor that international judicial decisions cite prior relevant national judicial decisions. ${ }^{14}$ Judicial citation is indeed one of the most seductive tools the legal profession is trained to resort to. Making reference to a prior judicial decision can operate as an example of good practice, of quality legal reasoning, of material recollection, but also as a warning against bad practice, to depart from prior legal reasoning and propose better solutions to the issue at hand, or as an example of inaccurate methodologies. ${ }^{15}$

This paper seeks to offer a fresh perspective on the phenomenon of judicial citation, particularly by focusing on the additional value this practice can bring to the understanding of contemporary international law-making. In order to conduct this inquiry, I will focus on judicial decisions on points of international criminal law. This delimitation is justified as follows. First, international criminal law took shape and developed chiefly through the activity of international criminal tribunals. ${ }^{16}$ There hence exists a congruous body of international case law pertaining to international crimes. International case law established by the International Military Tribunal in Nuremberg (IMT) and the ad hoc tribunals, the International Criminal Tribunal for the Former Yugoslavia (ICTY) and the International Criminal Tribunal for Rwanda (ICTR), undisputedly have authority in the ambit of international criminal law, not least by the simple fact that international crimes were almost exclusively the domain of those tribunals. ${ }^{17}$ As expressed by some scholars, the 'epistemic community' of international lawyers traditionally regards the international judicial fora as the preferred venue for the undertaking of normative development of this branch of law. ${ }^{18}$ Secondly, the completion strategy set in motion by the ad hoc tribunals envisions the closure of those tribunals, which have been at the forefront of international criminal justice and are still authoritative for many substantive international criminal law issues. In that event, more emphasis will necessarily be placed on domestic judicial

12. See Y Shany, 'Seeking Domestic Help - The Role of Domestic Criminal Law in Legitimizing the Work of International Criminal Tribunals' (2013) 11 JICJ 5.

13. See, for example, A Zammit Borda, "The Notion of "Persuasive Value" of External Precedent in International Criminal Law' (2015) 84 Nordic Journal of International Law 29, 32. 14. See H van der Wilt, 'National Law. A Small but Neat Utensil in the Toolbox of International Criminal Tribunals' (2010) 10 International Criminal Law Review 209, 211: 'After all, "harmonization" does not imply full fledged "unification". But it is incontrovertible that international criminal tribunals have a normative impact on domestic jurisdictions.' Ibid 240: 'Interaction between international criminal tribunals and domestic jurisdictions is here to stay. It implies the impact of international criminal tribunals on the law and practice of national jurisdictions, but, reversely, the lasting influence of domestic law on international tribunals as well.' .

15. On the point, see J Bell, 'Researching Globalization: Lessons from Judicial Citations' (2014) 3 CJICL 961.

16. E van Sliedregt, Individual Criminal Responsibility in International Law (OUP, Oxford 2012) 5, referring to the law-making process through judicial interpretation.

17. This statement takes into consideration the event of trials set up within domestic jurisdictions alongside the IMT based on the Control Council Law n. 10, as well as other historical international crimes trials carried out domestically, such as the Eichmann case in Israel, the Barbie case in France and others.

18. H Van der Wilt, 'Domestic Courts' Contribution to the Development of International Criminal Law: Some Reflections' (2013) 46 Israel Law Review 207, 207. 
actors and on newly international judicial institutions. Thirdly, an increasing number of domestic jurisdictions became active in the prosecution and adjudication of international crimes in the wake of the affirmation of the principle of universal jurisdiction attached to those crimes or par effet of the ratification of the Rome Statute. To this, one may add that the very existence of a plurality of adjudicatory actors - national and international - in international criminal law suggests that judicial institutions do not operate in a vacuum but interact and relate to one another. ${ }^{19}$ It is contended that this is evidenced inter alia through a phenomenon of judicial citation in courts' case law. While interpreting international law and adjudicating international crimes they all participate in the activity of shaping international law. ${ }^{20}$

This article addresses the questions of how and why domestic courts refer to prior international and foreign domestic judicial decisions; ${ }^{21}$ whether international judicial decisions exhibit deference to national judicial decisions, and if so, how this practice is justified. This paper does not aim to provide a full-fledged taxonomy of interactions between international and national judicial decisions. Rather, it operates a prima facie distinction of judicial citations as a finding device or as a justification exercise. The difference between these two types of judicial citation practices is significant. A court may turn to prior relevant judicial decisions in the wake of a finding activity, whereby the content of a certain norm is construed by reference to prior judicial decisions; or it may rather dwell on an activity of justification where the decision on a certain point of law has already been taken and judicial citation has the mere function of supporting that finding. Judicial citation as a practice of finding arguably sets out an element of 'newness' which is relevant for understanding the ways in which a judicial pronouncement creates normative expectations in international law and arguably contributes to the making of international law.

Section 2 considers the notion of international law-making and the role of domestic judicial decisions in the theory of sources of international law. Caveats in relation to law-making and law-creating will be duly addressed in this context. Section 3 will introduce judicial citation as a technique of international law-making in contemporary international law and it will outline selected instances of judicial citation with a view to suggesting a prima facie distinction between judicial citation as a finding device or as a justification exercise. Finally, section 4 will draw conclusions on the revival of domestic courts in international law-making.

\section{CONTEMPORARY INTERNATIONAL LAW-MAKING: NEW PARADIGMS?}

Traditionally, the notion of international law-making points at the methods whereby legally binding rules are created. Legal scholars have understood these methods to be

19. For a thorough reflection on the modern relationship between domestic and international courts, see J Nijman and A Nollkaemper (eds), New Perspectives on the Divide Between National and International Law (OUP, Oxford 2007).

20. The notion of international law-making which I use throughout this article is defined below in looser terms than the process of creating binding rules of international law. To underline this nuance, I at times refer to the 'shaping' of international law or to 'forming' international law. 21. This type of judicial reference has also been termed external as opposed to internal jurisprudence and it is employed here in the same terms. See A Zammit Borda, 'The Use of Precedent as Subsidiary Means and Sources of International Criminal Law (2013) 18 Tilburg Law Review 65, 66. See also E Voeten, 'Borrowing and Nonborrowing among International Courts' (2010) 39 The Journal of Legal Studies 547, 548. 
treaties, custom and general principles of law recognised by civilised nations. ${ }^{22}$ There are two main consequences of such an understanding: on the one hand, international lawmaking has been conceived as a State-driven activity, thus blurring the distinction between the lawmakers and the addressees of those very norms; ${ }^{23}$ on the other hand, international law-making as a process has been ontologically conflated with the sources of international law which actually result from law-making processes. This paper stresses the idea that Article 38 of the Statute of the International Court of Justice (ICJ Statute) ${ }^{24}$ which codifies formally recognised sources of international law, ${ }^{25}$ does not make any mention of how those sources are actually formed or shaped in the wide international arena.

Notwithstanding the fact that treaties and custom retain their universal recognition as sources of international law, ${ }^{26}$ contemporary legal scholarship has started devoting attention to other methods, avenues and processes that may generate binding rules or simply shape the content of pre-existing ones. Some scholarly contributions attempt to theorise international law-making beyond the contours of the traditional State-driven, rectius executive-driven, activity and to conceive of international law-making in a wider sense. For instance, Christine Chinkin and Alan Boyle offer a rather broad definition of international law-making, arguing that it 'encompasses the practices which give form and content to international law' ${ }^{27}$ This is the operational definition of international law-making which this paper subscribes to.

Such a definition has the merit of conceiving of international law-making as a wider notion than the concept of law made through sources of international law, ${ }^{28}$ as well as of opening up to actors other than States, which yet participate in the shaping of international law. International law-making is thus understood as a polycentric process, diffuse in nature, whereby international law is formed and shaped through the action of a plurality of actors interpreting and applying international law. Not only States, but also international organisations, non-State actors, non-governmental organisations and international judicial and quasi-judicial bodies among others all arguably take part in such processes. Domestic and international courts undisputedly play an important role in giving form and content to international law in relation to the increasing judicialisation of international law and the growing relevance of international law in domestic contexts.

\subsection{International law-making and the role of judicial decisions: why citing matters}

International law is increasingly becoming a domestic undertaking. While in the past, international law emerged before municipal courts in a limited number of instances, today municipal courts are becoming more engaged with the adjudication of

22. G Schwarzenberger, A Manual of International Law (6th edn, Professional Books Ltd, Abingdon 1976). See A Cassese, International Law (2nd edn, OUP, Oxford 2005) 153.

23. Ibid.

24. Statute of the International Court of Justice 39 AJIL Supp. 215 (1945) (ICJ Statute).

25. J Crawford, Brownlie's Principles of Public International Law (8th edn, OUP, Oxford 2008) 20.

26. As a reflection of this, art 38 of the ICJ Statute is regarded as customary in nature.

27. A Boyle and C Chinkin, The Making of International Law (OUP, Oxford 2007) 1.

28. On the distinction between formal and material sources of international law, see I Brownlie, Principles of Public International Law (7th edn, OUP, Oxford 2008) 1-4; A Pellet, 'Article 38 of the ICJ Statute', in C Tomuschat and others (eds), The Statute of the International Court of Justice - A Commentary (OUP, Oxford 2006) 714 ff. 
international law issues. This appears to be a common proposition among a number of scholars. ${ }^{29}$ Nevertheless, this does not per se entail that international law has changed in nature, paradigms and features. It may simply mean that an international scholar may turn, more often now than before, to domestic decisions to understand the meaning of a certain rule of international law. Plainly, decisions of domestic courts appear increasingly to gain momentum in international law.

Traditionally, Article 38(1)(d) of the ICJ Statute regards judicial decisions as a subsidiary means for determining the rules of law. Among judicial decisions, national ones have the additional value of contributing to the creation of customary international law pursuant to Article 38(1)(b) ICJ Statute insofar as they are evidence of State practice vis-à-vis a certain matter of international law. ${ }^{30}$ From this it follows that international law acknowledges the role of domestic courts in at least two respects: first, in their capacity as State organs, they contribute to State practice and, as such, to the formation of customary international law; secondly, they deliver decisions which are regarded as subsidiary means for interpreting the rules of law pursuant to Article 38(1)(d) ICJ Statute. ${ }^{31}$ In none of these instances can domestic courts be seen merely as international law appliers or addressees. ${ }^{32}$ On the contrary, international law acknowledges the active role played by domestic courts in giving form and content to the law qua State organs and through their judicial decisions. As such, Article 38 ICJ Statute offers guidance to the interpreter by enumerating the sources of international law. Yet, Article 38 ICJ Statute does not specify how international law is made, formed and shaped by the relevant agents operating in the field of international law. To illustrate, Article 38 ICJ Statute points to international custom as a source of international law, say the absolute prohibition of torture, but does not provide elements to infer how international custom is formed, that is, how States came to believe themselves to be legally bound to abide by the absolute prohibition of torture. If we accept that international law-making is the whole of processes, avenues and methods by which international law is made, formed and shaped, it is reasonable to conclude that Article 38 ICJ Statute is silent on international law-making, namely on the techniques, processes and factors which determine normative expectations in international law.

Interestingly, in the context of international criminal law, the Statute of the International Criminal Court introduces Article 21 Rome Statute which is derogatory to the general scope of Article 38 ICJ Statute as it provides for a hierarchy of sources of international law that the Court shall apply. According to Article 21(1)(c) Rome Statute, the Court may invoke, failing the investigation into the sources enumerated in Article 21(1)(a) and (b), ${ }^{33}$ general principles of law derived 'from national laws of legal systems of the world including, as appropriate, the national laws of States

29. See, for example, J d'Aspremont, 'The Systemic Integration of International Law by Domestic Courts: Domestic Judges as Architects of the Consistency of the International Legal Order' in OK Fauchald and A Nollkaemper (eds), The Practice of International and National Courts and the (De-)Fragmentation of International Law (Hart Publishing, Oxford 2012) 141; Roberts (n 5).

30. International Law Commission (ILC), 'Third Report on the Identification of Customary International Law' (2015) A/CN.4/682, 42-43; ILC, 'Report on the Work of the Sixty-Eighth Session' (2016) A/71/10, 109-10.

31. To this, one may add that national courts' decisions may help establish the existence of general principles of law in the terms of art 38(1)(c) ICJ Statute.

32. On the point, see A Tzanakopoulos and C Tams, 'Domestic Courts as Agents of Development of International Law' (2013) 26 LJIL 513, 518.

33. Art 21(1)(a) Rome Statute provides that the Court shall apply in the first place the Statute, Elements of Crimes and its Rules of Procedure and Evidence; whereas art 21(1)(b) sets forth 
that would normally exercise jurisdiction over the crime.' This formulation suggests that the Court would refer to comparative criminal law as a subsidiary source of law. ${ }^{34}$ For the sake of examining judicial citation in the ambit of international criminal law, it is worth noting that Article 21 mentions judicial decisions neither as a source of law nor as subsidiary means to determine the rules of law. In particular, Article 21 is silent on whether the Court may refer to the case law laid down by the ad hoc tribunals. ${ }^{35}$ In the case Prosecutor v Kony et al., Pre-Trial Chamber II established that 'the rules and practice of other jurisdictions, whether national or international, are not as such "applicable law", ${ }^{36}$ Regardless, citing the ICTY and ICTR jurisprudence appears to fall within the ICC judicial practice. ${ }^{37}$

Judicial citation as a phenomenon in international law suggests reconsidering the role and preponderance of domestic jurisdictions in the shaping process of international law norms and, as such, has the potential of adding value to the understanding of contemporary avenues of international law-making. Two assumptions lie at the heart of this presumed link between practices of judicial citation and international law-making. First, international legal texts may entail a certain degree of indeterminacy and it is especially in the context of judicial decisions that the meaning of those texts is shaped. In interpreting international rules, judicial decisions fix an instant image of the existing law which, though relatively stable, undergoes a continuous process of content-shaping. As a consequence of international legal texts being indeterminate, judicial decisions necessarily register and underscore an element of novelty in the law which has not yet been formalised in prior judicial decisions, or in the lex lata. ${ }^{38}$ The extent to which this novelty results from new evidence of State practice coupled with opinio juris or from the creative action of the judicial machinery is often a matter of persuasive argumentation techniques of judges. One of these techniques consists in citing international and/or foreign domestic judicial decisions to support or discharge a particular line of legal reasoning.

The second assumption pertains to the authority of judicial decisions in international law and is closely connected to the first one. From the assumption that international legal texts may contain an element of indeterminacy, it follows that judicial decisions, among other tools, may be determinative of the content of international law norms and that they may henceforth operate as an avenue creating normative expectations vis-à-vis States, in

applicable treaties and the principles and rules of international law, including the established principles of the international law of armed conflict, as sources that the Court shall apply in the second place, where appropriate.

34. WA Schabas, The International Criminal Court: A Commentary on the Rome Statute (OUP, Oxford 2010) 393.

35. V Nehlich, 'The Status of ICTY and ICTR Precedent in Proceedings Before the ICC' in C Stahn and G Sluiter (eds), The Emerging Practice of the International Criminal Court (Martinus Nijhoff Publishers, Leiden 2009) 312-17.

36. See Prosecutor v Kony et al. (Decision on the Prosecutor's Position on the Decision of Pre-Trial Chamber II to Redact Factual Descriptions of Crimes in the Warrants of Arrest, Motion for Reconsideration, and Motion for Clarification) ICC 02/04-01/05 (28 October 2005), referred in G Bitti, 'Article 21 of the Statute of the International Criminal Court and the Treatment of Sources of Law in the Jurisprudence of the ICC' in C Stahn and G Sluiter (eds), The Emerging Practice of the International Criminal Court (Martinus Nijhoff Publishers, Leiden 2009) 296-7.

37. See, for example, Prosecutor v Thomas Lubanga Dyilo (Decision on the Confirmation of Charges) ICC 01/04-01/06 (29 January 2007).

38. See J Pauwelyn, R Wesser and J Wouter, Informal Law Making (OUP, Oxford 2013). 
a similar vein as international treaties or customs do. In other words, international law is subject to the transformative effect of judicial interpretation performed by courts. Written laws take shape in the pronouncements of national and international judges, becoming 'part and parcel of the legal sense of the community'. ${ }^{39}$

It is debatable whether judicial decisions of international and municipal jurisdictions have progressively abandoned their ambit of subsidiary means for determining the rules of law in favour of a law-creating function. ${ }^{40}$ If this were so, it would certainly underscore an important departure from the traditional understanding of judicial decisions within the sources of international law. For instance, Georg Schwarzenberger describes judicial decisions as 'merely evidence of international law or, to be more exact, law-determining agencies for ascertaining the contents of the actual rules of international law' ${ }^{41}$ Hence, judicial decisions have a declaratory function, not a creative function. Once it is admitted that judicial decisions exhibit the content of international rules and that they are law-determining agencies declaratory of the content of existing rules, the new body of material produced by domestic and international jurisdictions warrants constant analysis.

Hersch Lauterpacht in part objects to this view challenging the

[largely accepted opinion] that, under a most favourable construction, municipal decisions are only evidence of custom, but not a factor creating customary international law (...) Viewed from another angle, this attitude is the outcome of the rigid separation of the judicial from the legislative functions in the direction of totally divorcing the work of judges from law-making proper. ${ }^{42}$

Lauterpacht theorises instead that municipal courts, qua organs of the State, 'are a source of customary international law in so far as they are uniform and in regard to states the courts of which have participated in the creation of such uniformity., 43 Municipal judgments 'do not produce express and immediate obligations in the same manner as a treaty does (...) But their cumulative and indirect effect is to give expression to the opinio juris of the highest judicial organs of the state. ${ }^{44}$

One point is noteworthy. Both scholars agree that the municipal decisions of a single State cannot per se create a rule of international law, rather that 'concordant decisions in pari materia on the part of courts of several states participate in the creation of a customary rule of international law. ${ }^{45}$ Accordingly, the conceptualisation of judicial decisions as the mere verbal articulation of what the law says is reasonably facing constant challenges in modern international law. In particular, international jurisdictions are traditionally bestowed with a role of prominence in "shaping the structure and content of international law, 46 and have considerably influenced some areas of

39. H Lauterpacht quoted in M Shahabuddeen, Precedent in the World Court (CUP, Cambridge 1996) 1.

40. See, for example, J Powderly and S Darcy (eds), Judicial Creativity at the International Criminal Tribunals (OUP, Oxford 2010).

41. G Schwarzenberger, A Manual of International Law (6th edn, Professional Books Ltd, Abingdon 1976) 18.

42. H Lauterpacht, 'Decisions of Municipal Courts as a Source of International Law' (1929) 10

British Yearbook of International Law 65, 66.

43. Ibid 81.

44. Ibid 84 .

45. Ibid 85 .

46. F Zabiyev, 'Judicial Activism in International Law' (2012) 3 Journal of International Dispute Settlement 247, 248. 
international law, including international criminal law, human rights law, and international trade law. The questions raised by this shift of understanding are whether there is a distinction to be made between international and domestic judicial decisions, and under which conditions a judicial decision exceeds the boundaries of its interpretive activity to perform a law-creating function.

This problématique of distinguishing between law-creation and law-application is a canonical one in international law doctrine. ${ }^{47}$ According to more contemporary commentators, judicial decisions may be elevated to law-creating processes inasmuch as they make international law by interpreting international law. ${ }^{48}$ In particular, it is submitted that '[p]ast interpretations generate normative expectations" ${ }^{49}$ and that 'the interaction between a number of actors in a transnational legal process is "jusgenerative". 50

The analysis of judicial decisions of municipal and international jurisdictions is germane for understanding whether and, if so, how domestic courts resort to prior international judicial decisions relevant for the matter to decide; whether and, if so, how domestic judicial decisions are used in the context of international judicial decisions; and what is suggested by the instances of judicial cross-reference from the viewpoint of international law-making.

\section{JUDICIAL CITATION: FINDING DEVICE OR JUSTIFICATION EXERCISE?}

In this section, I seek to examine selected instances of judicial citation in order to operate a prima facie distinction between judicial citation as a finding device or as a justification exercise. As I mentioned earlier, the paper does not provide a full-fledged taxonomy of judicial citation. Rather it utilises the pair finding/justification as a prima facie classification of selected instances of judicial citation practices. The latter will offer a starting point to reflect on the extent to which international criminal jurisdictions have cited prior judicial decisions of domestic courts and for which purpose, as well as to what extent national jurisdictions deciding on international criminal law matters have cited prior international case law. This inquiry will enable me to operate an embryonic test on the following hypotheses: i) domestic courts cite international judicial decisions primarily in a realm of finding, as a reflection of the authority retained by international judicial pronouncements in international law matters; ii) international jurisdictions cite domestic case law as a justification technique. Although this investigation considers a narrow sample of judicial decisions, the benefit of it is to trigger fresh reflections on the practices of judicial citations, rather than providing conclusive answers on this phenomenon. ${ }^{51}$ Should these hypotheses not be verified, this

47. See, for example, A von Bogdandy and I Venzke, 'Beyond Dispute: International Judicial Institutions as Lawmakers' (2011) 12 German Law Journal 979, 985 citing H Kelsen, Law and Peace in International Relations (Harvard University Press, Cambridge 1942).

48. See I Venzke, How Interpretation Makes International Law (OUP, Oxford 2012).

49. I Venzke, 'Contemporary Theories and International Law-making', in CM Broelmann and Y Radi (eds), Research Handbook on the Theory and Practice of International Law-Making (Edward Elgar, Cheltenham 2014) 9-10.

50. Ibid 14 referring to R Cover, 'Nomos and Narrative' (1983) 97 Harvard Law Review 4; ME O'Connell, 'New International Legal Process' (2004) 36 Studies in Transnational Legal Policy 79, 104.

51. This article is part of an ongoing doctoral project entitled 'New Perspectives in International Law-Making: The Dynamics of Judicial Citation in International Criminal Law' (Working Title). 
study will still enable me to reflect on the similar/dissimilar attitude of international and national jurisdictions adjudicating on international criminal law matters, as well as ponder on whether the centre of authority concerned with the interpretation and application of international criminal law is possibly and progressively migrating towards domestic courts.

\subsection{Domestic and international judicial decisions in international case law}

In terms of chronology, international criminal jurisdictions started citing domestic case law earlier than domestic courts embarked on the same enterprise of referring to their international criminal counterparts. One such example is traceable in the case law of the ICTY.$^{52}$ In the seminal Tadic decision on jurisdiction, ${ }^{53}$ the ICTY Appeals Chamber makes reference to the Danish case Prosecution v Refik Saric for the purposes of clarifying whether the notion of grave breaches of the 1949 Geneva Conventions may extend beyond the context of international armed conflicts. ${ }^{54}$ The Chamber is already clear on the answer to this question, namely that the notion of grave breaches and the obligations stemming therefrom upon States only apply in the context of international armed conflicts. ${ }^{55}$ However, the Chamber refers to contra evidence, with the purpose of underscoring elements of State practice which would potentially allow the application of the notion of grave breaches and the obligations of States attached thereto, regardless of the nature of the conflict: ${ }^{56}$

However, we are aware that this conclusion may appear not to be consonant with recent trends of both States practice and the whole doctrine of human rights (...) which tend to blur in many respects the traditional dichotomy between international law and civil strife. In this connection the Chamber notes with satisfaction the statement in the amicus curiae brief of the Government of the U.S. [which] provides the first indication of a possible change in the opinio juris of States (...) Other elements pointing in the same direction can be found in the provisions of the German Military Manual whereby grave breaches of international humanitarian law include some violations of common Article 3 (...) One can also mention a recent judgment of a Danish Court. On 25 November 1994 the Third Chamber of the Eastern Division of the Danish High Court delivered a judgment on a person accused of crimes committed together with a number of Croatian military police on 5 August 1993 in the Croatian prison camp of Dretelj in Bosnia (The Prosecution v. Refik Saric, unpublished (Den.H. Ct. 1994). The Court explicitly acted on the basis of the 'grave breaches' provisions of the Geneva Conventions (...) without however raising the preliminary question of whether the alleged offenses had occurred within the framework of an international rather than an internal armed conflict (...) This judgment indicates that some national courts are also taking the view that the 'grave breaches' system may operate regardless of whether the armed conflict is international or internal. ${ }^{57}$

52. The present contribution analyses a limited number of cases drawn from international case law databases, that is, the Oxford Public International Law Reports (OPIL) and the International Crimes Database of the Asser Institute. However, the author considers this sample of cases illustrative of broader practices.

53. Prosecutor $v$ Tadić (Decision on the Defence Motion for Interlocutory Appeal on Jurisdiction) ICTY-94-1-A (2 October 1995).

54. Ibid 83.

55. Ibid 80 .

56. Ibid 83 .

57. Ibid. 
The Danish case Prosecution v Refik Saric is regarded by the Chamber as an element of State practice on the same strength of the US statement and of the relevant provisions of the German Military Manual. From a legal viewpoint, this overview may resemble an attempt to reconstrue a norm of international customary law through State practice and opinio juris elements. However, this would have been relevant, had the Chamber not yet determined the issue $a b$ initio. What seems a plausible reading of the Chamber's methodology is instead that the Danish judicial decision is invoked to show, and possibly promote, a progressive approach to the interpretation of the notion of grave breaches. In this way, the Chamber's exercise is a device of justification to explain departure from State practice which is not yet reflective of the majority of States or even consistent.

Likewise, in Prosecutor v Anto Furundžija ${ }^{58}$ the ICTY Trial Chamber answered the question of whether or not the prohibition of torture had attained the status of a customary norm of international law. After recalling relevant conventional instruments, as well as domestic law in force in the Federal Republic of Yugoslavia, which proscribed torture, ${ }^{59}$ the Chamber operates in passing a noteworthy exercise, contending that:

The Trial Chamber does not need to determine whether the Geneva Conventions and the Additional Protocols passed into customary law in their entirety, as was recently held by the Constitutional Court of Colombia, or whether, as seems more plausible, only the most important provisions of these treaties have acquired the status of general international law. ${ }^{60}$

The question before the bench offered the Chamber the opportunity to review the finding of the Colombian Constitutional Court about an issue of international law, namely the crystallisation of the 1949 Geneva Conventions and of the two 1977 Additional Protocols into customary international law. ${ }^{61}$ As in the Tadić decision, the outcome is twofold: on the one hand, the outreach of the Colombia Constitutional Court's decision arguably expands and acquires a wider resonance; on the other hand, the Chamber shows caution in aligning itself with the findings of the Colombian Court, granting customary status to norms which presumably have not attained such a broad acknowledgment. With regard to the latter, again this is an instance where judicial citation operates as justification.

In the Decision on the confirmation of charges against Lubanga Dylo, ${ }^{62}$ the Pre-Trial Chamber was confronted with the interpretation of the notions of international armed conflict and non-international armed conflict. The Chamber recalls that the Rome Statute does not provide for a definition of international armed conflict and, in conformity with Article 21 of the Rome Statute on the applicable law, will refer to applicable treaties and principles and rules of international law to determine the issues. ${ }^{63}$ Interestingly, in discussing the internationalisation of a non-international armed

58. Prosecutor v Anto Furundžija (Judgment) ICTY-95-17/1-T (10 December 1998).

59. Ibid 134-6.

60. Ibid 137.

61. In the case Prosecutor $v$ Ramalingam/Liberation Tigers of Tamil Eelam (Judgment) The Hague District Court, The Netherlands, Case Nr. BU9716 (21 October 2011), the Dutch Court corroborates this finding, maintaining that APII has assumed the character of customary international law.

62. Prosecutor v Thomas Lubanga Dyilo (Decision on the Confirmation of Charges) ICC 01/04-01/06 (29 January 2007).

63. Ibid 205. 
conflict as a consequence of the intervention of agents acting on behalf of a foreign State, the Chamber refers to the 'overall control test' developed by the ICTY Appeals Chamber in the Tadic case ${ }^{64}$ and affirms that this is the standard to be used to establish whether armed forces are acting on behalf of another State. ${ }^{65}$ Judicial citation is resorted to here with a view to determine the meaning of 'international armed conflict', hence as a finding device.

As to the determination of the existence of a non-international armed conflict, the Chamber interprets the letter of Article 8(2)(e) of the Rome Statute in light of ICTY jurisprudence. In particular, the elements of duration and organisation contained in the expression 'protracted armed violence between governmental authorities and organized armed groups or between such groups within a State' of Article 8(2)(e) is formulated according to the wording of the Appeals Chamber Decision in Tadic ${ }^{66}$ not in conformity with the formulation of Article 1 of the Additional Protocol II to the 1949 Geneva Conventions. From this it follows that the drafters of the Rome Statute upheld the standard spelt out in the ICTY rather than adhering to the letter of the Additional Protocol II (APII). This is an eloquent instance, insofar as it demonstrates the impact which a judicial decision - subsequently upheld in a number of cases - may produce on the understanding of a provision of international law, namely Article 1 APII.

\subsection{International and foreign domestic cases in domestic case law}

The analysis of domestic cases also evidences the practice of judicial citation of prior international and foreign domestic judicial decisions. Two domestic cases, both concerned with the crime of genocide, are scrutinised. The comparison of these two instances grants us the opportunity to illustrate divergences and similarities in the reasoning of national judges confronted with a crime under international law. The first case was brought against Mr François Bazaramba and was adjudicated by a Finnish District Court in 2011 based on the universality principle. ${ }^{67} \mathrm{Mr}$ Bazaramba was charged with genocide for having killed Tutsis, ordered the death of Tutsis and incited the commission of such killings in Nyakizu commune in 1994, with the intent to destroy in whole or in part the Rwandan Tutsis as a group. ${ }^{68}$ The legal basis for prosecuting acts of genocide before a Finnish Court is the Finnish Criminal Code which since 1974 incorporates the necessary provisions to criminalise and punish acts of genocide as defined by Article 2 of the Convention on the Prevention and Punishment of the Crime of Genocide ('Genocide Convention'). ${ }^{69}$ As rightly recalled by the Court, the criminalisation of the crime of

64. Ibid 210, referring to Prosecutor v Tadić (Judgment) ICTY-94-1-A (15 July 1999) 84, 137.

65. Ibid 211.

66. Prosecutor $v$ Tadić (Decision on the Defence Motion for Interlocutory Appeal on Jurisdiction) ICTY-94-1-A (2 October 1995) 70.

67. Prosecutor v François Bazaramba (Judgment) Porvoo District Court (now District Court of Itä-Uusimaa), Finland, 10/423, Docket Nr. R09/404 (11 June 2011) 29.

68. Mr Bazaramba was of Hutu ethnicity, living in Nyakizu commune and, because of his active involvement in local politics and his vicinity to the mayor of Nyakizu, allegedly held at that time a de facto authority over the Hutu in Nyakizu. Further, Mr Bazaramba was 'in a position to acquire the weapons used in the genocide and to give monetary rewards to the Hutu who took part in the killings.'

69. Convention on the Prevention and Punishment of the Crime of Genocide (adopted 9 December 1948, entered into force 12 January 1951) 78 UNTS 277. 
genocide is based on the Genocide Convention to which Finland is bound under international law. ${ }^{70}$ In appraising the case, the Court clarifies that the provisions of the Convention are not as such binding on the Court although Finland is a party to the 1948 Genocide Convention. This entails that, formally, the Court is not bound to apply the provisions contained in the international convention but is only bound to apply the criminal provisions contained in the Finnish Criminal Code which materially reflect the provisions of the Genocide Convention. ${ }^{71}$

The Court's reasoning articulates itself in three steps. First, the Court acknowledges the lack of 'living justice', namely the scant existence of Finnish domestic case law interpreting the letter of the Genocide Convention ${ }^{72}$ from which to infer the constitutive elements of the crime of genocide. Secondly, the Court turns to international law instruments, namely the Genocide Convention and the Vienna Convention on the Law of Treaties, ${ }^{73}$ to find guidance in the interpretation of the substance of the constitutive elements of the crime of genocide. Thirdly, despite reaffirming the importance of domestic sources of law as the starting point of its appraisal of the case, the Finnish Court acknowledges the 'heightened' international nature of a genocide trial in a domestic court and the opportunity to refer to international case law and doctrine. In this regard, the Court recalls that

[t]he points of departure in Finnish criminal proceedings are always the application of the Finnish Criminal Code and the use of Finnish sources of law. Since in the manners recalled above, the genocide trial may be deemed to have a heightened international nature, the District Court has also studied the development and dogmatics of international criminal law as well as the case law of international criminal courts and tribunals. ${ }^{74}$

Notably, the Court refers to the case law established by the international tribunals (ICTY, Prosecutor v Jelisic ${ }^{75}$ and ICTR, Prosecutor v Bagosora ${ }^{76}$ ), to the writings of renowned international scholars in the field of international criminal law (Gerhard Werle) and to the French Criminal Code (Article 211-1) in order to establish whether the international definition of genocide requires the prosecution to prove the existence of a plan or genocidal policy (as claimed by the defendant). ${ }^{77}$ Plainly, this instance of judicial citation constitutes an exercise of finding whereby the Court becomes cognisant of the ways in which genocide has been adjudicated in prior international judicial decisions, and regarded by legal scholars and in foreign domestic criminal systems. From a legal point of view, coupling together international case law and reference to the teachings of the most highly qualified scholars in the field appears in consonance with Article 38(1)(d) ICJ Statute, to the extent that they are used as subsidiary means to determine the law. On the contrary, reference to the

70. Ibid 28 .

71. Finland is regarded as a dualist legal system. See M Scheinin (ed), International Human Rights Norms in the Nordic and Baltic Countries (Martinus Nijhoff Publishers, Leiden 1996) 14.

72. Prosecutor v François Bazaramba (n 67) 29.

73. Vienna Convention on the Law of Treaties (adopted 22 May 1969, entered into force 27 January 1980) 1155 UNTS 331.

74. Prosecutor v François Bazaramba (n 67) 29.

75. Prosecutor v Jelisić (Judgment) ICTY- IT-95-10-A (5 July 2001).

76. Prosecutor v Théoneste Bagosora et al (judgment) ICTR-98-41-T (18 December 2008).

77. Ibid 30. Interestingly, the Finnish Court relies on the findings of the ICTR (ICTR-98-44-T, Judgment of 11 December 2006) to determine the existence of a genocide in Rwanda in 1994, de facto taking judicial notice of the ICTR findings. See ibid 33. 
sole French Criminal Code proves ambiguous from the perspective of the sources of law.

The Finnish Court's reasoning articulates itself in the realm of finding, as the Court declares its necessity to look into prior adjudicated cases in order to find guidance on the interpretation of the crime of genocide. Notably, reference to international judicial decisions is used to interpret the relevant provisions of the Finnish Criminal Code which are reflective of those of the Genocide Convention. Hence, international and foreign domestic references are drawn upon ultimately to interpret Finnish domestic provisions on genocide. This is made possible by qualifying the crime as an international crime with a 'heightened nature'. Remarkably, the language spoken by the Finnish Court is ultimately an international language, ${ }^{78}$ accessible to any other domestic court and overcoming the insularity of domestic law when adjudicating a crime under international law.

A similarly recent case, $R$. v Munyaneza ${ }^{79}$ decided upon by a Canadian District Court presents analogies with the Finnish case illustrated above. ${ }^{80}$ This is the first genocide trial adjudicated in a criminal court of Canada based on the Crimes Against Humanity and War Crimes Act (S.C. 2000, c. 24) which came into force on 23 October 2000 (the Act). ${ }^{81}$ The case is relevant for the phenomenon of judicial citation because it deals with the notion of 'intentional killing' (first count of genocide) mentioned in international conventional instruments but not present in the Canadian Criminal Code. ${ }^{82}$ As observed by the Court, the use of the term 'intentional killing' in the Act differs from 'culpable homicide as murder' in the Criminal Code, therewith implying that "the Canadian legislator wished to refer to the definition of "intentional killing" found in international law and its jurisprudence' ${ }^{83}$

On 19 October 2005 Mr Desiré Munyaneza, a Rwandan national residing in Canada, was charged, inter alia, with two counts of genocide by intentional killing and through causing serious bodily or mental harm to the Tutsi people committed in the Prefecture of Butare in Rwanda between 1 April 1994 and 31 July 1994, with the intent to destroy the Tutsi in whole or in part, as defined in subsections 6(3) and 6(4) of the Act. ${ }^{84}$ The definition of genocide provided by subsection 6(3) of the Act reads as follows:

an act or omission committed with the intent to destroy, in whole or in part, an identifiable group of persons, as such, that at the time and in the place of its commission constitutes genocide within the meaning of customary international law or conventional international law or

78. On the point, see E Benvenisti and GW Downs, 'National Courts, Domestic Democracy, and the Evolution of International Law' (2009) 20 EJIL 59, 66.

79. R. v Munyaneza [2009] RJQ 1432.

80. Although Canada is party to the Rome Statute, this is not an instance of complementarity since the case concerns acts committed in Rwanda in 1994, before the Rome Statute came into force in 2002. It is instead an instance of universal jurisdiction casting light on how the domestic judge reads and applies prior international case law.

81. Canada, although traditionally regarded as a dualist system, has embraced a more monistoriented approach. For an overview of this development, see S Beaulac, 'Recent Developments on the Role of International Law in Canada Statutory Interpretation' (2004) 25 Statute Law Review 19.

82. R. v Munyaneza (n 79) 81.

83. Ibid 82.

84. Ibid 69. 
by virtue of its being criminal according to the general principles of law recognized by the community of nations. ${ }^{85}$

The judgment recalls that the Genocide Convention is the foundation of treaty law as it pertains to genocide, the definition of which (Article 2 of the Convention) has been incorporated verbatim in the Statute of the ICTY and of the ICTR, as well as the Rome Statute.

With a view to determining the content of the law at the time of the commission of the alleged crimes, the Canadian judge makes reference to the Musegera case, a previous case adjudicated in Canada, asserting that even without a conventional definition, the crime of genocide in 1994 was in contravention of all the peremptory norms of customary international law. ${ }^{86}$ In addition, the court in Munyaneza finds assistance in the foundational instruments of international tribunals (including the ICC to which Canada is party) and in the case law of the ICTY and ICTR to interpret the meaning of 'intentional killing' (Prosecutor v Brdanin ${ }^{87}$ ). The same approach is followed to ascertain the meaning of 'serious bodily or mental harm' for which the Court also explicitly refers to the ICTR and ICTY jurisprudence (Prosecutor $v$ Akayesu $^{88}$ and Prosecutor v Kajelijeli ${ }^{89}$ ).

Interestingly, the Canadian Court refers and draws authority from both ad hoc tribunals, not merely from the ICTR, which was specifically mandated to deal with the Rwandan genocide. As noted by some commentators, 'international criminal law and jurisprudence acted as guidance for the court in defining those offences ["intentional killing", "serious bodily and mental harm", etc...]', 90 evidencing a significant degree of deference to the ad hoc tribunals' case law. In a similar way to the Bazaramba case, the Munyaneza judgment denotes an 'internationally-oriented, outward-looking view that the CAHWC [Canada's Crimes Against Humanity and War Crimes Act 2000] clearly demands of Canadian law', although more willing to cite relevant domestic case law than foreign national precedents. ${ }^{91}$

Once again, judicial citation of prior international judicial decisions responds to findings undertaken rather than justificatory practices. An explanation thereof may reside in the authority traditionally retained by international jurisdictions for interpreting and applying international law. National courts emerge as reluctant to take up the challenge of interpreting and applying international law without citing prior relevant case law.

\section{CONCLUSIONS AND PROSPECT FOR FURTHER INVESTIGATION}

This contribution has shown that, despite the limited selection of judicial decisions, both international and domestic judicial decisions exhibit judicial citation on points of international criminal law. The cases analysed allow us to advance a preliminary claim: whereas in domestic judicial decisions judicial citation prima facie results in an exercise of finding, international case law tends to invoke domestic judicial decisions as a

85. Ibid 70 .

86. Musegera $v$ Canada (Minister of Citizenship and Immigration) [2005] 2 SCR 100.

87. Prosecutor v Brdanin (Trial Chamber judgment) ICTY IT-99-36-T (1 September 2004).

88. Prosecutor v Akayesu (Trial Chamber judgment) ICTR-96-4-T (2 September 1998).

89. Prosecutor v Kajelijeli (Trial Chamber judgment) ICTR-98-44A-T (1 December 2003).

90. RJ Currie and I Stancu, 'R. v Munyaneza: Pondering Canada's First Core Crimes Conviction' (2010) 10 International Criminal Law Review 829, 848.

91. Ibid 850 . 
justification device. Given space constraints and the limited instances of case law analysed, these conclusions are to be confined to this pilot study and would require further investigation to be capable of generalisation or formulated in absolute terms.

As demonstrated by the Bazaramba case in Finland, citing international judicial decisions and foreign domestic law sources responds to the 'heightened' nature of crimes under international law, which result from violations of peremptory norms. The analysis of domestic judicial citation displays a prima facie deference to international judicial decisions for the interpretation of substantive rules of international criminal law. Articulated in the realm of finding, international judicial decisions are indeed referred to as guidance to the interpretation of international criminal law, or - more accurately - to a widely-supported interpretation of international law rules.

On the contrary, judicial citation in the selected instances of international judicial decisions manifests itself as a device of justification, whereby the international judge appears to invoke prior domestic judicial decisions to justify departure from their findings but at the same time to promote a more progressive interpretation of the same rules of international law.

Considering the increasing role that national jurisdictions will play in the adjudication of international crimes in the future, more specifically the increasing involvement of domestic jurisdictions in the interpretation and application of international law, it is suggested that the dynamics of judicial citation will likely pave the way towards interdomestic judicial cross-references, signalling the migration of authority from international jurisdictions to domestic jurisdictions.

In terms of international law-making, instances of judicial citation as a finding exercise are germane to foster the scholarly debate of how international judicial decisions shape international law and create expectations on domestic courts qua State organs regarding how to decide a certain matter of international law. Noticeably in the ICTY case law, such normative expectations do not seem to be generated, at least not with regard to these instances, by domestic judicial decisions. Further investigating domestic judicial decisions on points of international criminal law - and international law at large may be revelatory of practices of mutual interaction (including influence) between international and domestic courts and among domestic courts themselves, underscoring elements of continuity between the international and the municipal law sphere rather than separation, as emphasised by the classic monism-dualism opposition. ${ }^{92}$

In other words, investigating the practices of judicial citation has the potential of enhancing the comprehension of how a certain understanding of an international law rule is formed. In other words, citing a given prior judicial decision, be it national or international, is associated with processes whereby national and international jurisdictions perceive of themselves as normatively compelled to align their decisions with or depart from that prior case law.

92. G Gaja, 'Dualism - A Review' in J Nijman and A Nollkaemper (eds), New Perspectives on the Divide Between National and International Law (OUP, Oxford 2007) 56. 